\title{
Improving Learning with Model Cooperative Learning SDN 4 Sambongrejo
}

\section{Tri Dodok Suryatiningsih}

SDN 4 Sambongrejo

tridodoksuryatiningsih33@gmail.com

\section{Article History}

accepted 14/11/2020

approved $21 / 11 / 2020$

published $26 / 11$

\begin{abstract}
The purpose of the study to improve learning was carried out in pre-cycle from the number of 18 students applying Cooperative Learning, teachers gave formative test questions, achieved the completeness of 9 students with a breakdown of 90 grades as many as 3 students, 80 grades as many as 3 students, obtained a score of 70 as many as 3 students, not yet 9 students, scored 60 as many as 5 students and 50 as many as 4 students, the highest score of 90 , the lowest value is 50 . Average value is 68. Learning cycle I number of 18 students, who achieved completion as many as 12 students details a score of 90 as many as 4 students, a score of 80 as many as 4 students, who obtained a score of 70 as many as 4 students, who have not completed 6 students, the highest score of 90, the lowest score of 60 . The average score of 74 cycle II learning from 18 students is a score of 90 as many as 6 students, a score of 80 as many as 6 students, a score of 70 as many as 6 students, a high score of 90 and a low score of $70 \mathrm{An}$ average score of 80 is determined by $\mathrm{kkm} 70$ school.
\end{abstract}

Keywords: Learning, cooperative learning model

\begin{abstract}
Abstrak
Tujuan penelitian memperbaiki pembelajaran dilaksanakan pada pra siklus dari jumlah 18 siswa menerapkan Cooperative Learning, guru memberikan soal tes formatif, mencapai nilai ketuntasan 9 siswa dengan rincian nilai 90 sebanyak 3 siswa,nilai 80 sebanyak 3 siswa, memperoleh nilai 70 sebanyak 3 siswa, belum tutas 9 siswa, perolehan nilai 60 sebanyak 5 siswa dan 50 sebanyak 4 siswa, nilai tertinggi 90 , nilai terendah 50 .Nilai rata-rata 68. Pembelajaran siklus I jumlah 18 siswa, , yang mencapai ketuntasan sebanyak 12 siswa rincian nilai 90 sebanyak 4 siswa,nilai 80 sebanyak 4 siswa, yang memperoleh nilai 70 sebanyak 4 siswa, yang belum tuntas 6 siswa,nilai tertinggi 90 , nilai terendah 60 .Nilai rata-rata 74 Pembelajaran siklus II dari 18 siswa adalah nilai 90 sebanyak 6 siswa, nilai 80 sebanyak 6 siswa ,nilai 70 sebanyak 6 siswa, nilai tertinggi 90 dan nilai terendah 70 Nilai rata-rata 80 ditentukan sekolah KKM 70.
\end{abstract}

Kata kunci: Pembelajaran, model cooperative learning

Social, Humanities, and Education Studies (SHEs): Conference Series https://jurnal.uns.ac.id/shes

p-ISSN 2620-9284 e-ISSN 2620-9292 


\section{PENDAHULUAN}

Dalam kegiatan pembelajaran, seorang guru senantiasa berharap yang akan disampaikan kepada siswa, dapat diterima dengan baik. Namun harapan tidak selamanya dapat terwujud dalam kenyataan guru melaksanakan proses pembelajaran pada akhir kegiatan memberikan tes formatif hasil penilaian yang diperoleh tidak semua siswa dapat mencapai nilai yang diharapkan ,sebagai bukti hasil penilaian yang diperoleh masih sangat rendah .Rendahnya hasil belajar siswa, guru mencari factor penyebab dari rendahnya hasil belajar yang diperoleh,factor penyebab mungkin siswa kurang aktif dalam mengikuti pembelajaran,tidak bersemangat belum termotivasi, sarana dan prasarana yang kurang memadai, perhaatian guru kepada kepada siswa ketika kegiatan pembelajaran .

.Pembelajaran pada prinsipnya, adalah memberikan pengetahuan kepada siswa supaya memiliki berbagai pengalaman,banyak,wawasan, untuk mengetahui berbagai macam kejadian dan peristiwa yang ada dimuka bumi yang menyangkut berbagai macam makluk hidup dan kehidupan, maupun benda tak hidup, yang sangat berguna dan bermanfaat dalam kehidupan untuk dipelajari dapat membantu siswa memahami permasalahani secara dalam.

Pembelajaran untuk menekankan kepada siswa supaya memiliki tanggung jawab diberikan bekal pengalaman melalui pembelajaran yang aktif, kreatif, dan menyenangkan, menumbuhkan aktifitas yang tinggi memiliki gagasan menemukan untuk menghasilan penguasaan ilmu pengetahuan yang baru dengan cara melibatkan siswa supaya lebih giat dalam belajar melakukan kegiatan tindakan yang sesuai dengan tujuan yang telah direncanakan untuk mengadakan,kegiatan untuk melakukan kegiatan percobaan/demonstrasi akan sangat bermakna bagi siswa. Teori belajar mengatakan, bahkan belajar yang efektif harus melalui pengalaman. belajar melalui pengalaman (learning by doing) dalam bentuk eksplorasi dan manipulasi akan menjadikan sesuatu yang dipelajari diingat untuk waktu lama (long term memory). Dalam penelitian ditemukan bahwa seseorang akan mengingat dan menggunakan kembali pengetahuan diperoleh, sebelumnya apabila pengetahuan tersebut dihasilkan dari upaya "mengonstruksi" sendiri (Mc. Namara \& Helay, 1995).

Penelitian tindakan kelas dilaksanakan untuk peningkatan aktivitas,sehingga dapat memperoleh hasil belajar lebih baik pengamatan dari peneliti menunjukkan kualitas proses belajar mengajar masih kurang atau rendah. Mungkin disebabkan alat peraga,media pembelajaran seharusnya disediakan supaya dapat memudahkan membantu guru dalam menyajikan materi kepada siswa kelas $\mathrm{V}$ apabila hal tersebut belum terpenuhi sehingga siswa kurang tertarik terhadap guru ketika memberikan penjelasan ,pada kegiatan selanjutnya untuk belajar memecahkan masalah secara kelompok masih terdapat banyak siswa kurang bertanggung jawab terhadap tugas diberikan guru.

Untuk mengatasi rendahnya kualitas proses dan hasil belajar yang masih rendah dilakukan perbaikan kegiatan dengan menerapkan model pembelajaran Konstruktivisme pembelajaran Cooperative Learning dengan memanfaatkan alat peraga dalam bentuk menerapkan Model pembelajaran Kooperatif merupakan interaksi dalam kelompok teman sebaya (Damon dan Phelps, 1989). Pembelajaran Cooperative Learning adalah kegiatan belajar mengajar dengan cara membentuk kelompok kecil; siswa belajar dan bekerja sama untuk sampai kepada pengalaman belajar yang optimal, baik pengalaman individu maupun kelompok (Johnson, 1991). Dari pengertian ini tersirat tiga karakteristik pembelajaran Cooperative Learning melalui kelompok kecil, belajar/bekerja sama, dan pengalaman belajar. Dalam strategi ini siswa dikelompokkan secara heterogen dengan pola anggota siswa dengan pemahaman tinggi, pemahaman rendah, siswa dengan pemahaman rata-rata, sehingga akan terjadi interaksi komunikasi diantara anggota kelompok . 
Pembelajaran Cooperative Learning merupakan model pembelajaran yang didalamnya siswa bekerja sama untuk mencapai tujuan khusus atau menyelesaikan sebuah tugas. Dalam pembelajaran ini nampaknya adanya komponen utama dipersiapkan untuk melaksnakan kegiatan pembelajaran .

Penerapan model pembelajaran di sekolah untuk peningkatan kualitas proses dan hasil belajar (nilai ulangan harian atau tes formatif setiap siswa harus memperoleh nilai kreteria yang ditentukan dengan ketuntasan belajar secara klasikal harus mencapai $80 \%$ ). Dengan pembelajaran secara kelompok karena jumlah siswa dalam kelas 18 siswa maka setiap kelompok ditentukan beranggotakan 6 siswa untuk memecahkan masalah secara bersama,ketuntasan belajar siswa dapat tercapai secara maksimal terjadi peningkatan keaktifan dan partisipasi, minat belajar dalam proses pembelajaran baik secara individu ( perorangan ) maupun kelompok sehingga terwujud paradigma pembelajaran dari teacher centered menuju ke students centered.

Berdasarkan landasan teoritik dimuka, maka sebagai peneliti untuk melaksanakan penelitian tindakan kelas dengan menggunakan model pembelajaran Cooperative Learning untuk peningkatan hasil belajar organ gerak hewan dan manusia. Dalam hal ini pada akhir kegiatan pembelajaran guru memberikan soal tes formatif dilaksanakan secara lisan dan tertulis untuk mengetahui keberhasilan pada akhir pertemuan hasil tes formatif pembelajaran dapat ditunjukkan dari hasil penilaian jumlah 18 siswa belum mencapai ketuntasan yang berarti penguasaan materi siswa masih perlu untuk ditingkatkan. Dengan berlandaskan hasil penilaian yang masih rendah kepala sekolah melaksanakan peneltian tindakan kelas,supaya guru menyusun rencana pelaksanaan pembelajaran untuk memperbaiki proses pembelajaran yang telah lalu sehingga pembelajaran yang berikutnya tidak terjadi kembali kegagalan yang ditunjukkan rendahnya hasil belajar siswa, guru untuk memperbaiki kepala sekolah sebagai peneliti,meminta supaya guru sebagai peneliti untuk memperbaiki proses pembelajaran, menerapkan model pembelajaran Cooperative Learning yang diharapkan supaya dapat tercapai peningkatan kualitas kegiatan pembelajaran dan hasil belajar siswa kelas V semester I di SDN 4 Sambongrejo,karena sekolah menentukan syarat siswa memenuhi ketuntasan belajar minimal sesuai dengan KKM 70 .

Berdasarkan uraian dari latar belakang masalah di atas maka sebagai peneliti menyusun merumuskan masalah sebagai berikut :

1. Apakah guru menerapkan model Cooperative Learning terdapat peningkatan aktivitas belajar organ gerak hewan dan manusia siswa kelas $V$ semester I di SDN 4 Sambongrejo tahun pelajaran 2020/2021?

2. Apakah guru menerapkan model Cooperative Learning terdapat peningkatan kemampuan belajar siswa kelas $\mathrm{V}$ semester I di SDN 4 Sambongrejo tahun pelajaran 2020/2021 ?

3. Apakah guru menerapkan model Cooperative Learning terdapat peningkatan hasil belajar organ gerak hewan dan manusia siswa kelas $\mathrm{V}$ semester I di SDN 4 Sambongrejo tahun pelajaran 2020/2021?

Guru melaksanakan kegiatan Penelitian dilaksanakan dalam rangka untuk mengetahuai tingkat keberhasilan kegiatan belajar mengajar yang dilaksanakan guru dan siswa kelas $\mathrm{V}$ semester I yang meliputi :

1) Untuk mengetahui sampai sejauh mana persiapan guru dalam menyusun persiapan untuk melaksanakan pembelajaran kepada siswa.

2) Guru hendaknya melaksanakan observasi kegiatan yang dilakukan siswa sehingga lebih aktif dan efesien dalam belajar.

3) Untuk memotivasi kepada siswa supaya memahami materi pelajaran yang dipelajari dengan mengkaitkan materi melaui kegiatan dalam konteks kehidupan sehingga siswa memiliki pengetahuan dan ketrampilan yang secara refleksi dapat diterapkan untuk memecahkan permasalahan . 
4) Menumbuhkan siswa untuk bersemangat dalam belajar sehingga menjadi bertanggungjawab dalam setiap tugas apapun yang diberikan oleh gurunya, sehinngga menumbuhkan kemandirian siswa.

\section{METODE}

Penelitian Tindakan Kelas (PTK) dilaksanakan di kelas IV SDN 4 Sambongrejo Jl. Sawur - Kalimiri Ds. Sambongrejo Kec.Sambong Kab.Blora 58371 pada semester ganjil bulan November sampai pada bulan Desember 2020.Subyek penelitian ini adalah siswa kelas $\mathrm{V}$ dengan jumlah peserta didik sebanyak 18 siswa terdiri 10 siswa laki-laki dan 8 siswa perempuan.Bertujuan untuk meningkatkan pemahaman peserta didik pada organ gerak hewan dan tumbuhan mengggunakan model cooperative learning.

Sumber data penelitian adalah guru pembelajaran tematik dan siswa kelas $\mathrm{V}$. Data awal diperoleh dari guru digunakan peneliti untuk melihat peningkatan pemahaman siswa pada organ gerak hewan dan tumbuhan setelah diterapkan model pembelajaran cooperative learning. Ada jenis data digunakan peneliti dalam pelaksanaan PTK yaitu : Data kualitatif merupakan suatu data berupa rincian keterangan, definisi, dan penjelasan yang dikategorikan berdasarkan kualitas objek akan diteliti. Data Kuantitatif adalah data yang didapat dengan cara mengumpulkan data melalui instrumen-instrumen penelitian yaitu lembar pengamata, dokumentasi dan tes formatif.

Adapun teknik pengumpulan data yang digunakan dalam penelitian adalah Observasi/pengamatan merupakan teknik/cara mengumpulkan data dengan cara mengadakan pengamatan terhadap kegiatan yang sedang berlangsung. Obsevasi ini dilakukan dengan mengamati jalannya proses pembelajaran tematik kelas V. Peneliti akan menggunakan kedua tekinik tersebut analisis kualitatif dan kuantitatif.

\section{HASIL DAN PEMBAHASAN}

Pada bagian pembahasan, diuraikan hasil kajian/penelitian dan hubungannya dengan kerangka teori atau kajian empirik terdahulu. Pada bagian ini dapat mnyertakan tabel dan gambar secara ringkas. Contoh penyajian tabel dan gambar sebagai berikutHasil penelitian pembelajaran Cooperative Learning peningkatan hasil belajar siswa kelas V semester I di SDN 4 Sambongrejo dibahas sebagai berikut :

Pembelajaran Pra Siklus

Hasil Belajar awalnya siswa kelas V nilai rata-rata pembelajaran sangat rendah khususnya khususnya dalam menggunakan pada kompetensi yang harus dikuasai dan perlu daya ingat yang setia sehingga mampu menguasai materi dalam jangka waktu lama. Sebelum dilakukan tindakan guru memberikan tes. Berdasarkan ketuntasan belajar siswa dari sejumlah 18 siswa terdapat 9 siswa atau $50 \%$ yang baru mencapai ketuntasan minimal, sedangkan 9 siswa atau $50 \%$ belum mencapai kriteria ketuntasan minimal yang ditentukan yaitu 70 sedangkan hasil nilai pra siklus terdapat nilai tertinggi 90 terendah 50 rata-rata kelas 68.

Berdasarkan grafik di bawah ini.

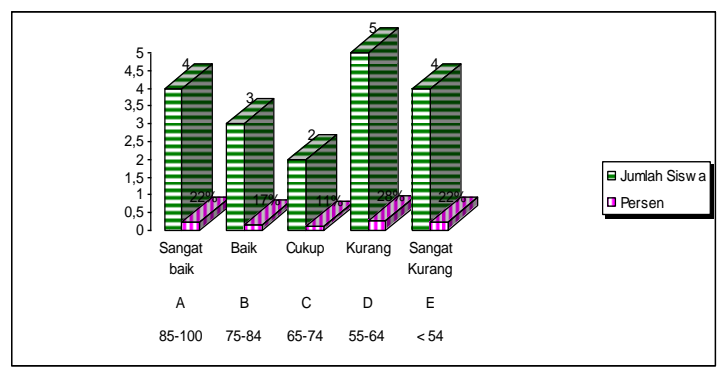

Grafik 1. Nilai pra siklus 


\section{SHEs: Conference Series 3 (3) (2020) 1364- 1373}

Dari hasil tes formatif pra siklus, menunjukkan hasil belajar yang mencapai nilai $A$ (sangat baik) adalah 3 siswa atau 22\%, sedangkan yang mendapat nilai B (baik) 6 siswa atau (33\%). Sedangkan yang mendapat nilai C (Cukup) 3 siswa atau (22\%) sedangkan yang mendapat nilai D (Kurang) 3 siswa atau (22\%) sedangkan yang mendapat nilai $\mathrm{E}$ (Sangat kurang) 0 siswa atau (0\%).

Tabel 1. Ketuntasan Hasil Belajar Pra Siklus

\begin{tabular}{cccc}
\hline No & Ketuntasan Belajar & \multicolumn{2}{c}{$\begin{array}{c}\text { Jumlah Siswa } \\
\text { Pra Siklus } \\
\text { Persen }\end{array}$} \\
\cline { 3 - 4 } & Tuntas & Jumlah & $50 \%$ \\
2 & Belum Tuntas & 9 & $50 \%$ \\
& Jumlah & 18 & $100 \%$ \\
\hline
\end{tabular}

Berdasarkan Ketuntasan Belajar Siswa dari sejumlah 18 siswa terdapat 9 siswa $(50 \%)$ yang sudah mencapai ketuntasan belajar. Sedangkan 9 siswa (50\%) belum mencapai ketuntasan belajar. Adapun dari hasil nilai siklus I dapat dijelaskan bahwa perolehan nilai tertinggi adalah 90 terendah 60 dengan nilai rata-rata 74

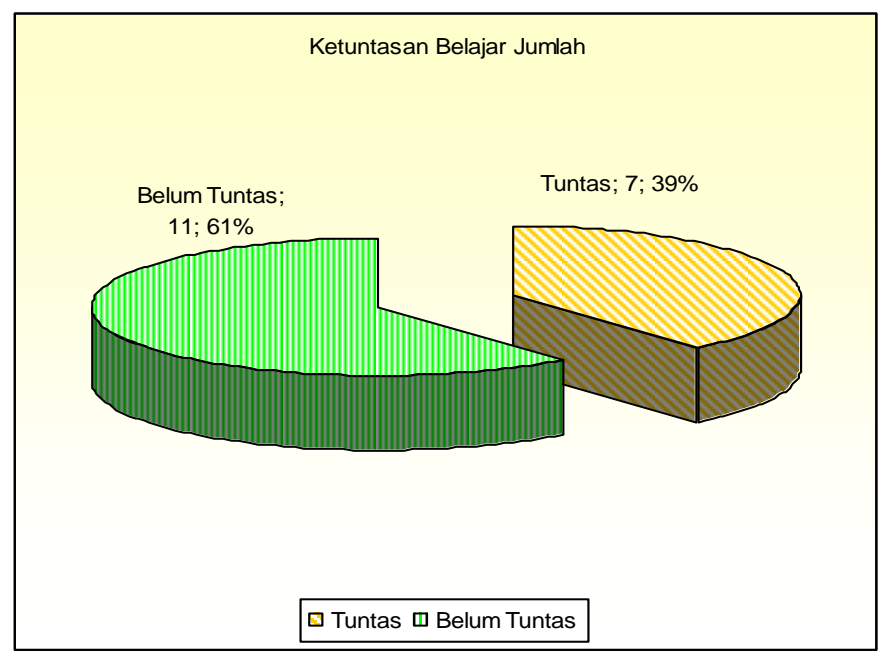

Grafik 2. Ketuntasan pra siklus

Tabel 2. Nilai Rata-Rata Siklus I

\begin{tabular}{clc}
\hline No & \multicolumn{1}{c}{ Keterangan } & Nilai \\
\hline 1. & Nilai tertinggi & 90 \\
2. & Nilai terendah & 60 \\
3. & Nilai rata-rata kelas & 74 \\
\hline
\end{tabular}


Berdasarkan data diatas digambarkan dengan grafik sebagai berikut :

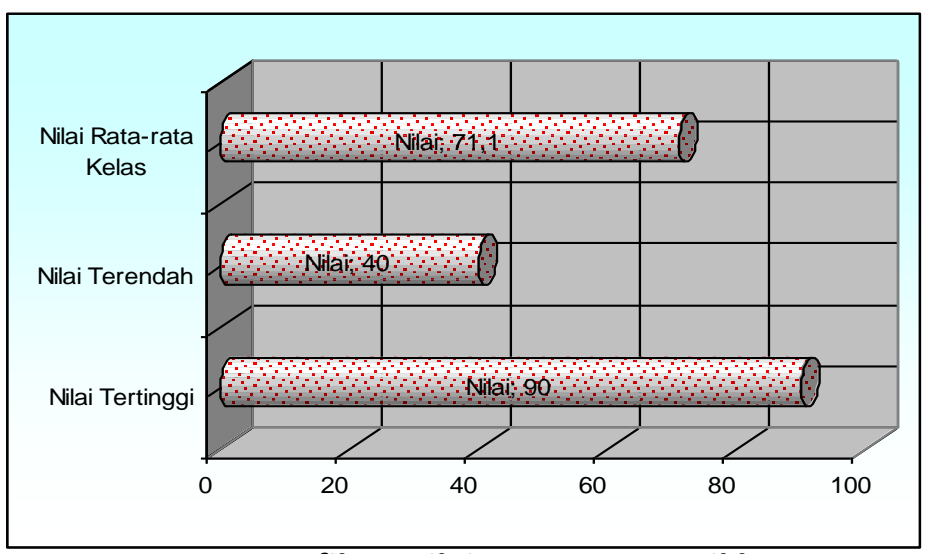

Grafik 3. Nilai rata-rata pra siklus

Proses Pembelajaran

Proses pembelajaran pada pra siklus menunjukkan bahwa siswa masih pasif, karena tidak diberi respon yang menantang.

Pembahasan Pembelajaran Siklus 1

Hasil tindakan pembelajaran pada siklus I berupa hasil tes dan non tes. Berdasarkan hasil observbasi yang dilakukan oleh penelitian terhadap pelaksanaan siklus I diperoleh keterangan sebagai berikut :

Hasil Belajar

Dari hasil tes siklus I, menunjukkan bahwa hasil yang mencapai nilai 6 siswa atau $33 \%$, sedangkan yang mendapat nilai 12 siswa atau $(67 \%)$ sedangkan yang mendapat nilai C 0 siswa $(0 \%)$ yang mendapat nilai 6 siswa $(0 \%)$ sedangkan yang mendapat nilai E 0 siswa atau $(0 \%$.)

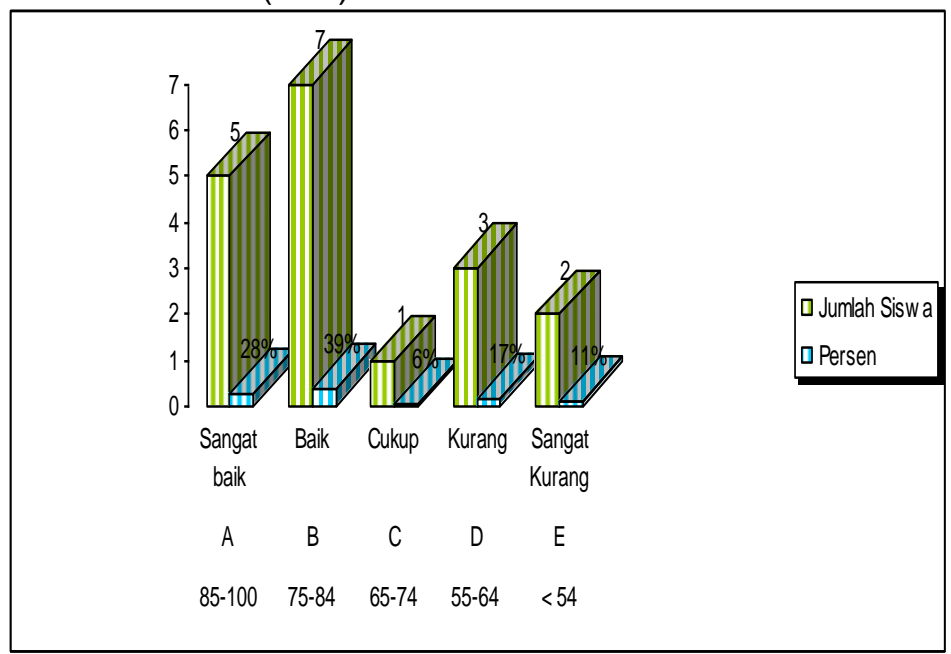

Grafik 4. Hasil nilai siklus I

Tabel 3. Ketuntasan Belajar Siswa Siklus I

\begin{tabular}{cccc}
\hline & & \multicolumn{3}{c}{$\begin{array}{c}\text { Jumlah Siswa } \\
\text { No }\end{array}$} & Ketuntasan Belajar & Jumlah & Persen \\
\hline 1 & & 12 & $67 \%$ \\
2 & Tuntas & 6 & $33 \%$ \\
& Belum Tuntas & 18 & $100 \%$ \\
\hline
\end{tabular}


Berdasarkan ketuntasan siswa dari sejumlah 18 siswa terdapat 12 siswa atau $67 \%$ yang sudah mencapai ketuntasan belajar. Sedangkan 6 siswa atau 33\%, belum mencapai ketuntasan. Adapun dari hasil nilai siklus I dapat dijelaskan bahwa perolehan nilai tertinggi adalah 90 nilai terendah 60 dengan nilai rata-rata kelas sebesar 74

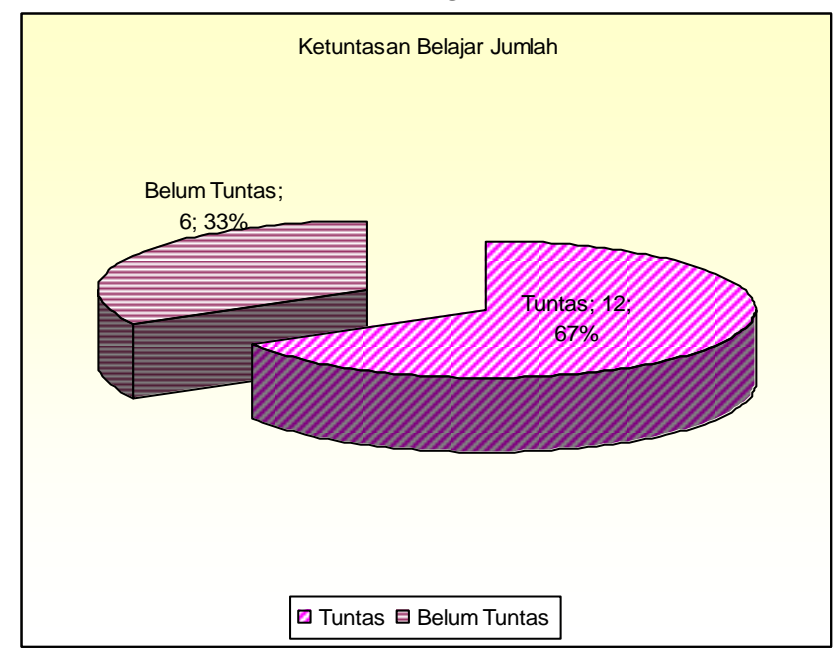

Grafik 5. Nilai rata-rata siklus I

Tabel 4. Rata-Rata Nilai Siklus I

\begin{tabular}{ccc}
\hline No & Keterangan & Nilai \\
\hline 1. & Nilai Tertinggi & 90 \\
2. & Nilai Terendah & 60 \\
3. & Nilai rata-rata kelas & 74 \\
\hline
\end{tabular}

Berdasarkan tabel diatas digambarkan dengan grafik sebagai berikut

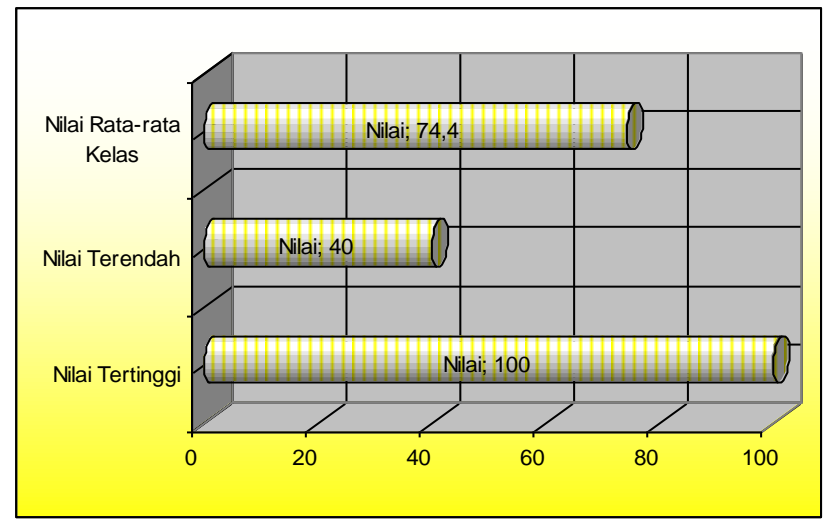

Grafik 6. Nilai Rata-rata Siklus I

Proses Pembelajaran

Proses pembelajaran pada siklus I sudah menunjukkan adanya perubahan, meskipun belum semua siswa terlihat aktif dalam kegiatan pembelajaran.

Hasil antara kondisi awal menyebabkan adanya perubahan walau pun belum bisa optimal, hal ini di tandai dengan peningkatan jumlah siswa yang mencapai ketuntasan belajar. 
Pembahasan Pembelajaran Siklus II

Hasil tindakan pembelajaran berupa hasil tes dan non tes, berdasarkan hasil observasi yang dilaksanakan peneliti terhadap pelaksanaan diperoleh keterangan sebagai berikut :

Dari pelaksanaan tindakan dapat diketahui bahwa yang mendapatkan nilai sangat baik (A) adalah 6 siswa (33\%). Sedangkan yang terbanyak yaitu yang mendapat nilai baik (B) adalah 12 siswa atau (67\%) sedangkan yang mendapat nilai (C) adalah 0 siswa ( $0 \%)$ sedangkan yang mendapat nilai (D) adalah 0 siswa atau ( $0 \%)$ dan $\mathrm{E}$ tidak ada atau $0 \%$ sedangkan nilai rata-ratanya kelas adalah 80 .

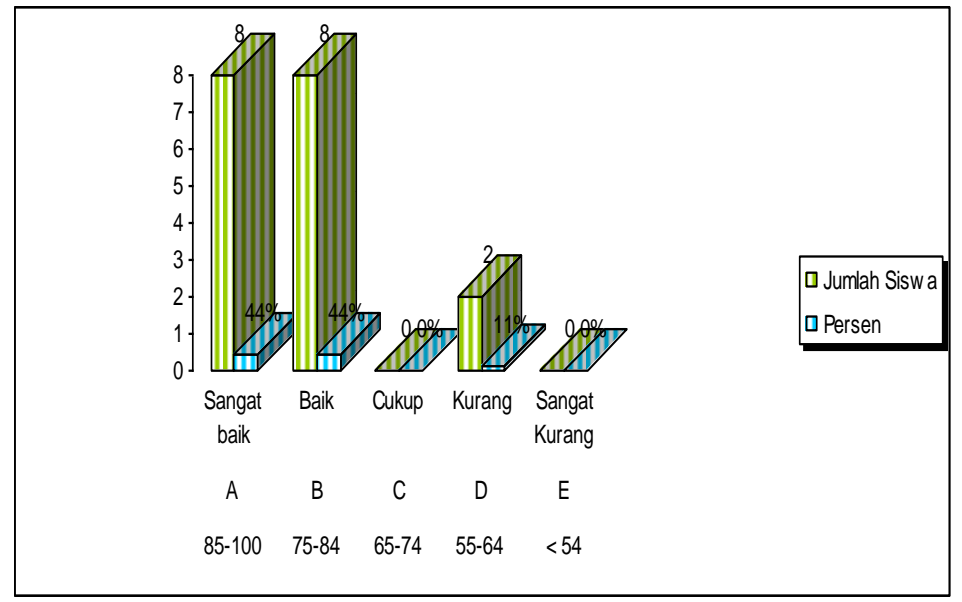

Grafik 7. Hasil belajar siklus II

Tabel 8. Ketuntasan Belajar Siklus II

\begin{tabular}{cccc}
\hline No & Ketuntasan Belajar & \multicolumn{3}{c}{$\begin{array}{c}\text { Jumlah Siswa } \\
\text { Siklus II }\end{array}$} \\
& & Jumlah & Persen \\
\hline 1 & Tuntas & 18 & $100 \%$ \\
2 & Belum Tuntas & 0 & $0 \%$ \\
& Jumlah & 18 & $100 \%$
\end{tabular}

Berdasarkan ketuntasan siswa dari sejumlah 18 siswa terdapat 18 siswa atau $100 \%$ yang sudah mencapai ketuntasan belajar. Yang berarti semua siswa mencapai ketuntasan nilai rata-rata 80 . Adapun dari hasil nilai siklus I dapat dijelaskan bahwa perolehan nilai tertinggi adalah 90 nilai terendah 60 dengan nilai rata-rata kelas sebesar 74 .

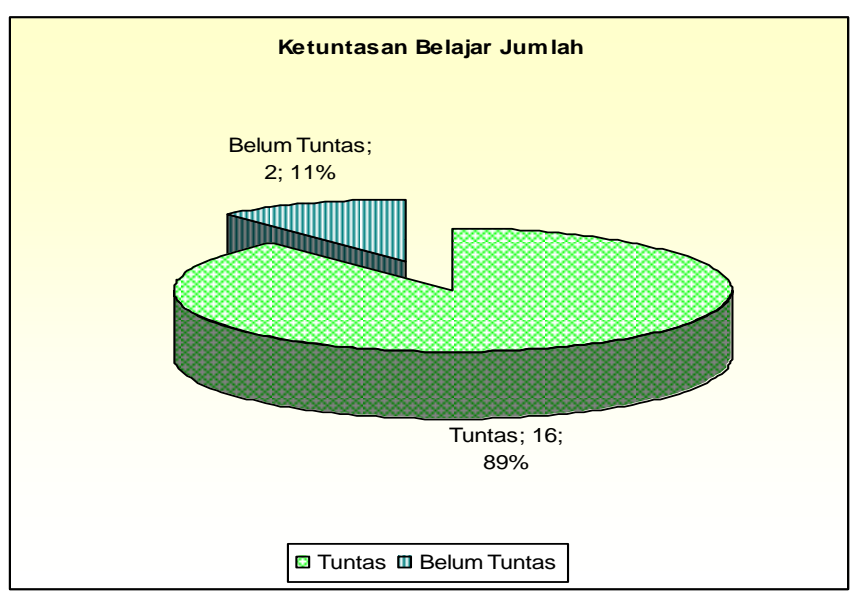

Grafik 8. Nilai rata-rata siklus II 
Tabel 9. Nilai Rata-Rata Siklus II

\begin{tabular}{lll}
\hline No & Keterangan & Nilai \\
\hline 1. & Nilai Tertinggi & 90 \\
2. & Nilai Terendah & 70 \\
3. & Nilai Rata-rata Kelas & 80 \\
\hline
\end{tabular}

Berdasarkan tabel diatas digambarkan dengan grafik sebagai berikut :

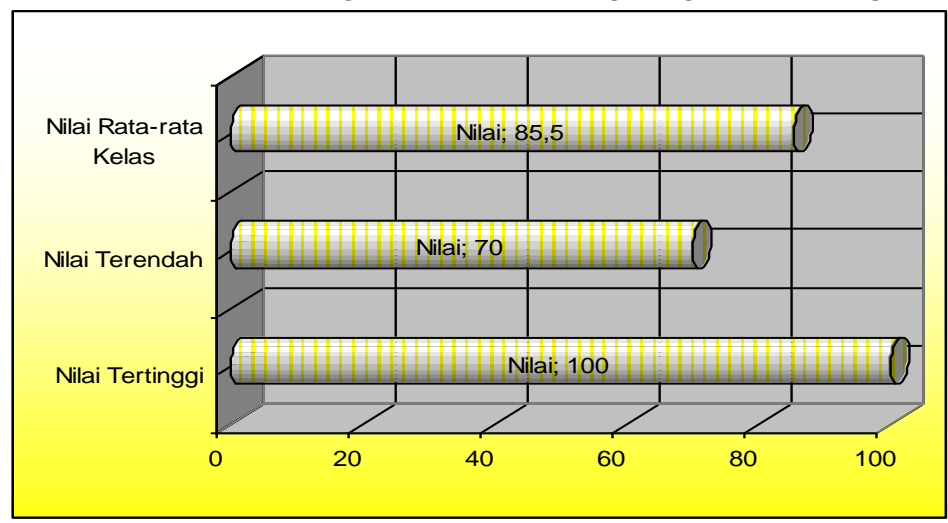

Grafik 9. Nilai rata-rata siklus II

Proses pembelajaran pada siklus II sudah menunjukkan semua siswa terlihat aktif dalam kegiatan pembelajaran. Dari hasil pengamatan telah terjadi kreatifitas dan keaktifan siswa secara mental maupun motorik, karena kegiatan pembelajaran yang dilakukan dengan permainan perlu kecermatan dan ketepatan. Ada interaksi antar siswa secara individu maupun kelompok, serta antar kelompok, masing-masing siswa ada peningkatan latihan bertanya jawab dan bisa mengkaitkan dengan mata pelajaran lain maupun pengetahuan umum, sehingga disamping berlatih ketrampilan bertanya jawab siswa berlatih berargumentyasi ada persaingan positif antar kelompok untuk penghargan dan menunjukkan jati diri pada siswa melakukan kegiatan yang positif

Dengan melihat perbandingan hasil tes siklus I dan siklus II ada peningkatan yang cukup signifikan, baik peningkatan yang cukup siknifikan, baik dilihat dari ketuntasan belajar maupun hasil perolehan nilai rata-rata 74 kelas. Dari sejumlah 18 siswa sudah mengalami ketuntasan dengan nilai rata-rata 80

Dari ketiga tabel dan grafik di atas menunjukkan adanya peningkatan hasil tes formatif siswa. pra siklus nilai rata-rata hanya 68 Siklus I mengalami peningkatan menjadi 74 dan Siklus II mengalami peningkatan lagi menjadi 80. Ini menunjukkan hasil tes formatif yang maksimal. Demikian juga tingkat ketuntasan prestasi belajar dari Pra Siklus hanya 50\% Siklus I menjadi 67\% dan Siklus II 100\%.

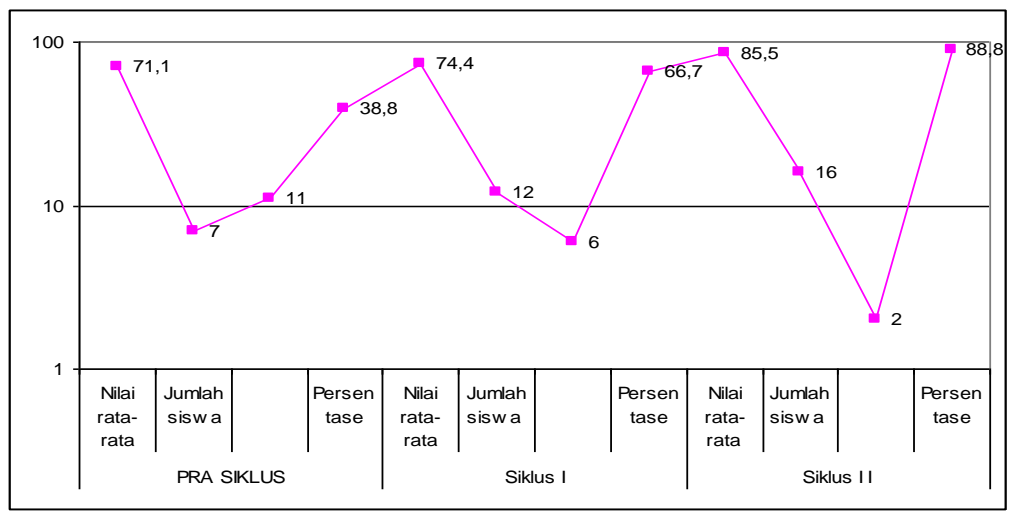

Grafik 10. Perbandingan Belajar Pra Siklus, Siklus I, Siklus II 


\section{SIMPULAN}

Berdasarkan hasil penelitian yang telah dilaksanakan oleh guru kelas $\mathrm{V}$ memperbaiki penyusunan program perbaikan pembelajaran melaksanakan kegiatan disimpulkan memperoleh hasil sebagai berikut :

Pembelajara pra siklus dari jumlah 18 siswa, guru memberikan soal tes formatif, yang mencapai nilai ketuntasan sebanyak 9 siswa dengan rincian nilai 90 sebanyak 3 siswa,nilai 80 sebanyak 3 siswa, nilai 70 sebanyak 3 siswa, yang belum mencapai ketuntasan 9 siswa, dengan perolehan nilai 60 sebanyak 5 siswa dan 50 sebanyak 4 siswa, nilai tertinggi yang diperoleh 90 , nilai terendah 50 .Nilai rata-rata 68 .

Pembelajaran siklus I menerapkan Cooperative Learning jumlah 18 siswa, guru memberikan tes formatif, yang mencapai nilai ketuntasan sebanyak 12 siswa dengan rincian yang memperoleh nilai 90 sebanyak 4 siswa,nilai 80 sebanyak 4 siswa, dan nilai 70 sebanyak 4 siswa, yang belum mencapai ketuntasan 6 siswa ,yang memperoleh nilai 60 sebanyak 6 siswa ,nilai tertinggi yang diperoleh 90 , nilai terendah 60 .Nilai rata-rata 74

Pembelajaran siklus II menerapkan Cooperative Learning) dari jumlah 18 siswa mengikuti kegiatan akhir yang dilaksanakan guru memberikan tes formatif nilai yang diperoleh siswa adalah nilai 90 sebanyak 6 siswa, , nilai 80 sebanyak 6 siswa nilai 70 sebanyak 6 siswa, nilai tertinggi yang dapat dicapai

\section{DAFTAR PUSTAKA}

Arikunto, Suharsimi 1998 : 5. Prosedur Penelitian Suatu Pendekatan Praktek. Penerbit Rineka Cipta. Jakarta.

Depdiknas. 2007. Bahan Ajar Pembelajaran IPA SD. Konsorsium PJJ SI PGSD. Depdiknas. Jakarta.

Depdikbud, (1994:6). Kurikulum Pendidikan Dasar GBPP Kelas V SD.

Dimyati dan Mudjiono. 1999. Belajar dan Pembelajaran. Jakarta : PT. Rineka Cipta.

Johson, D.W., dan Johnson, R.T., 1989. Cooperative and Competitive : Theory and Researc. Edina, WN : Interaction Book Co.

Khaerudin, 2007, Kurikulum Tingkat Satuan Pendidikan Konsep dan Implementasi di Madrasah. Jawa Tengah. Madrasah Development Center (MDC).

Lundgren, L., 1994. Cooperative Learning in the Science Classroom. New York : MC. Millan/MC. Graw - Hill.

Sulistyorini, Sri. 1999. Penerapan Pembelajaran Kooperatif Tipe Jigsaw pada Mata Pelajaran IPA. Lembaran IImu Pengetahuan. No. 1- tahun XXVIII-1999-11-19. Semarang : IKIP Semarang.

Sutrisno, Leo dkk., Pengembangan Pembelajaran IPA SD. Depdikmas, Jakarta, 2007. Suyoso (1998:23), Ilmu Alamiah Dasar. Yogyakarta: IKIP.

Slavin, Robert E. 1995. Cooperative Learning. Masscochusets : Allyn and Bacon Publisher.

Usman, Moh. Uzer dan Setiawan, Lilis (1993:5), Upaya Optimalisasi Kegiatan Belajar Mengajar, Bandung : PT. Remaja Rosdakarya, 1993. 